\title{
Metabolic Activity of Purified Suspensions of Mycobacterium lepraemurium
}

\author{
By B. S. TEPPER AND K. G. VARMA* \\ Johns Hopkins-Leonard Wood Memorial Leprosy Research Laboratory, \\ Department of Pathobiology, School of Hygiene and Public Health, \\ Baltimore, Maryland, 2I 205, U.S.A. \\ (Received 5 April 1972; revised 23 May 1972)
}

\begin{abstract}
SUMMARY
Metabolism of Mycobacterium lepraemurium harvested from infected mice was studied using radioisotope tracer techniques. ${ }^{14} \mathrm{C}$-labelled acetate, fumarate, glycerol, $\alpha$-ketoglutarate, glutamine and succinate were oxidized and assimilated, but at extremely low rates. Asparagine and glucose were assimilated but not oxidized. These data provide unequivocal evidence for the utilization of exogenous substrates by purified suspensions of $M$. lepraemurium and indicate the existence of a host-independent aerobic metabolism and an operative tricarboxylic acid cycle.
\end{abstract}

\section{INTRODUCTION}

Mycobacterium lepraemurium, the agent of a chronic granulomatous infectious disease in murine rodents, is an intracellular parasite which has so far not been cultured in cell-free media. Because of its similarity to $M$. leprae, $M$. lepraemurium has been used extensively as a model for human lepromatous leprosy in studies of comparative pathology, immunology and chemotherapy, and in attempts to obtain fundamental information toward the eventual cultivation of both organisms in vitro.

Although metabolic studies were made possible 20 years ago when Hanks (I95I $a$ ) devised a method for separating Mycobacterium lepraemurium from infected host tissue, there is still little known about the metabolism of this organism. Hanks (195 I $b, 1954$ ), isolated the organisms from rat testes and observed a weak endogenous anaerobic hydrogen transfer to tetrazolium violet which deteriorated rapidly and was not stimulated by exogenous nutrients. Gray (1952) measured the endogenous respiration of $M$. lepraemurium using manometric procedures and found that none of the 50 substrates or co-factors tested enhanced respiration. Subsequent reports (Ito \& Sonada, I958; Kusaka, I958 $a$; Tamemasa \& Tsutsumi 1958) have confirmed these findings for most substrates; however, there have been preliminary indications that $M$. lepraemurium can utilize asparagine (Ito \& Sonada 1958; Tepper, I97I); acetate and glycerol (Tepper, I97I); succinate (Kusaka, I958b); ribose (Kusaka, I959); and higher fatty acids, indole, skatole and $o$-aminophenol (Tamemasa \& Tsutsumi, 1958). In addition, there is recent evidence which suggests that $M$. lepraemurium may be capable of synthesizing at least some macromolecules in vitro: $M$. lepraemurium incubated in a modified Dubos medium elongated to 3 to 4 times its initial length without multiplying (Hart \& Valentine, 1963), and this increase in length was accompanied by a proportional increase in weight (Valentine, I962). Draper \& Hart (1968) measured some of the changes in

* Present address: Levindale Hebrew Geriatric Center and Hospital, Baltimore, Maryland, 2 I 2 I 5, U.S.A. 
$20 \mathrm{~g}$ of leproma in $40 \mathrm{ml}$ of distilled water, homogenized for 1-2 $\mathrm{min}$ in a Servall Omni-Mixer, $100 \mathrm{ml}$ of distilled water added.

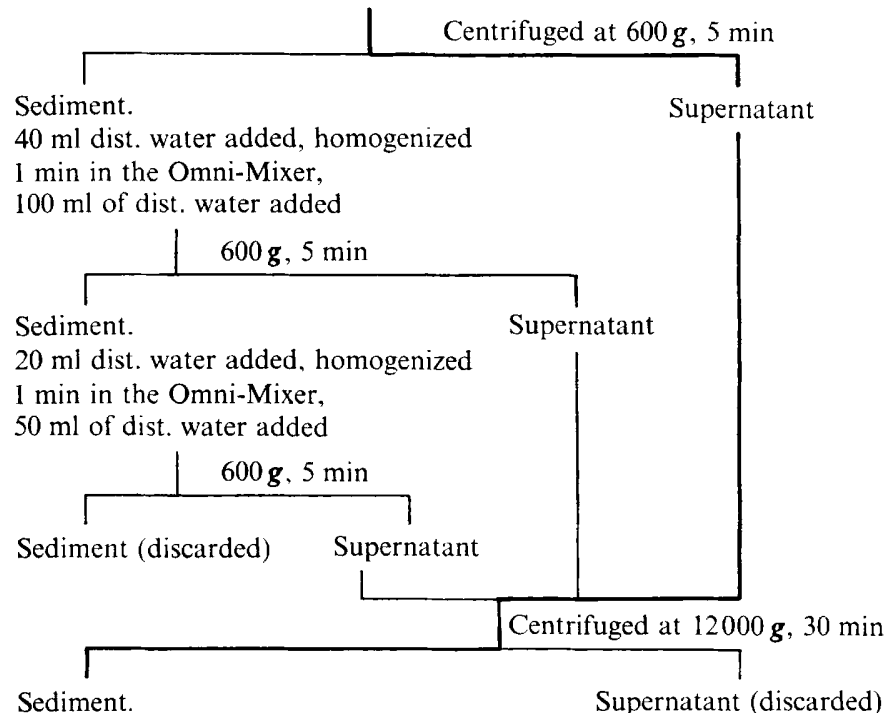

Sediment.

$40 \mathrm{ml}$ dist. water added, homogenized

$1 \mathrm{~min}$ in the Omni-Mixer,

$160 \mathrm{ml}$ of dist. water added

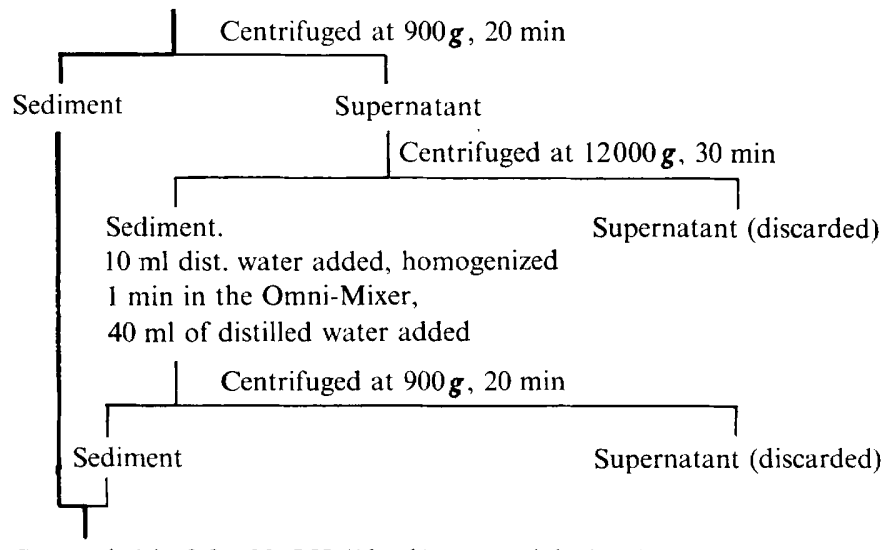

Suspended in $0.3 \mathrm{~N}-\mathrm{NaOH}(10 \mathrm{ml} / \mathrm{g}$ wet weight bacilli),

shake $15-20 \mathrm{~min}$, adjust $\mathrm{pH}$ to 6.8 with saturated

$\mathrm{KH}_{2} \mathrm{PO}_{4}(2 \mathrm{ml} / 10 \mathrm{ml} \mathrm{NaOH}$ suspension)

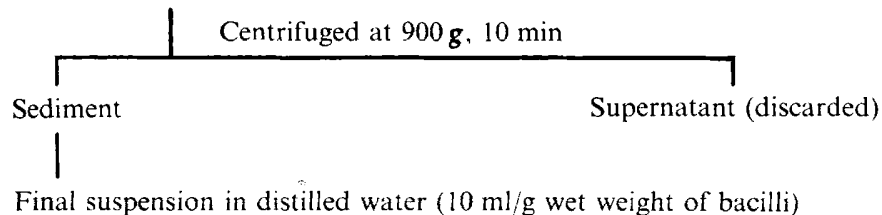

Fig. I. Method for the collection of Mycobacterium lepraemurium from infected mouse tissue. 
composition which occurred during elongation and found that lipid and neutral sugar accounted for over $60 \%$ of the weight gain, while phosphorous, $\alpha$-amino nitrogen, nucleic acid and hexosamine showed lesser increases. The substrates used for these syntheses were not determined. The present report describes the use of radioisotopic tracer techniques for determining substrate utilization in vitro by M. lepraemurium.

\section{METHODS}

Collection of the organism. The Hawaiian strain of Mycobacterium lepraemurium was harvested from female CFW mice (Carworth, Inc., New York City, New York, U.S.A.) which had been infected intraperitoneally 3 to 4 months previously with $1 \cdot 5 \times 10^{8}$ bacteria. Lesions in the pelvic and omental fat were removed aseptically and the bacteria freed from the tissue components by a modification of the method of Nishimura et al. (1967). The flow diagram (Fig. I) shows the alternate cycles of low- and high-speed centrifugations used to separate the bacteria from tissue components. All homogenizations and centrifugations were done at $4{ }^{\circ} \mathrm{C}$. The exposure of the mycobacterial suspensions to $0.3 \mathrm{~N}-\mathrm{NaOH}$ was used to kill contaminating organisms and so insure the inactivation and removal of residual host protein. The neuralization step prevented the irreversible clumping of the bacteria in suspensions subsequent to $\mathrm{NaOH}$ treatment. Occasionally, the main line of the separation, indicated by the darker line in Fig. I, was used for preparing bacterial suspensions. Yields of wet mycobacteria approximated $10 \%$ of the weight of the harvested tissue when the complete procedure was used and $2 \%$ when the main-line procedure was adopted.

Reaction system. Metabolic experiments were carried out in $25 \mathrm{ml}$ Erlenmeyer flasks which contained a reaction mixture consisting of $8 \mathrm{ml}$ of medium, buffer or diluent $(\mathrm{I} \cdot 25 \times$ concentration), I $\mathrm{ml}$ of labelled substrate, and I $\mathrm{ml}$ of the suspension of purified bacteria. The mycobacterial suspensions contained 0.23 to $\mathrm{I} \cdot 0 \mathrm{mg}$ bacterial nitrogen $/ \mathrm{ml}$ which corresponded to $3.3 \times 10^{9}$ to $1.5 \times 10^{10}$ bacteria/ml. Each flask was sealed with a serum bottle stopper which held a plastic cup, I $\mathrm{cm}$ above the level of the reaction mixture (Fain, Scow \& Chernick, 1963). Flasks were incubated at $37^{\circ} \mathrm{C}$, without shaking, for up to I4 days. After the desired incubation, the reaction mixtures were cooled to $4{ }^{\circ} \mathrm{C}$ and then $0.5 \mathrm{ml}$ of cold $50 \%(\mathrm{w} / \mathrm{v})$ trichloroacetic acid was injected into each flask.

Respired carbon dioxide was trapped in $0.2 \mathrm{ml}$ of $30 \%$ (w/v) KOH injected into the plastic cup of each reaction flask. After an additional $2.0 \mathrm{~h}$ at $4{ }^{\circ} \mathrm{C}$, with occasional swirling, each plastic cup with its contents was separated from its suspending rod and placed in the bottom of another $25 \mathrm{ml}$ Erlenmeyer reaction flask. The carbon dioxide was redistilled by acidification in the cold and trapped in Hyamine-hydroxide (Amersham/Searle Corporation, Des Plaines, Illinois, U.S.A.) contained in the suspended cup. The ${ }^{14} \mathrm{CO}_{2}$-Hyamine cup was placed in a liquid scintillation vial with $15 \mathrm{ml}$ of Bray's solution (Bray, 1960), and the radioactivity was determined in a Nuclear-Chicago Unilux II liquid scintillation system. Quench corrections obtained by internal standards or by channel ratio procedures were used in calculating absolute counts (d.p.m.).

Radioactivity assimilated into the bacteria was determined after the suspension was washed by centrifugation three times with $2.5 \%$ trichloracetic acid, once with $0 . \mathrm{I} \mathrm{N}-\mathrm{HCl}$, and then with distilled water until the radioactivity of the supernatant wash water was less than two times the background count. The residue was then solubilized at $60^{\circ} \mathrm{C}$ in $0.5 \mathrm{ml}$ Soluene 100 (Packard Instruments Co., Downers Grove, Illinois, U.S.A.) and then counted in Bray's solution in the liquid scintillation counter.

Under these conditions, variations among triplicate tests were usually less than Io \%. The 
results presented are the means of triplicate tests. Control flasks containing radioactive substrates without bacteria were put through the same procedures in order to determine a background count. These controls represented a significant proportion of the radioactivity detected in the trapped carbon dioxide and are reported in each experiment.

Contamination test. In each experiment extra flasks for each substrate were sampled for ${ }^{14} \mathrm{CO}_{2}$ activity before trichloroacetic acid was added to the experimental flasks. When such flasks showed unusually high activity, tests for contamination by other bacteria were made on all the reaction mixtures. A sample of reaction mixture $(0.2 \mathrm{ml})$ was withdrawn from each flask by a sterile tuberculin syringe and incubated in thioglycollate medium (Difco), thiol medium (Difco) and Lowentstein-Jensen medium (BBL). The majority of experiments were free of contaminants. When contamination was detected it was sporadic, usually occurring in less than $5 \%$ of the flasks. Data from contaminated flasks were rejected.

Chemical and microscopic analyses. The nitrogen contents of portions of the mycobacterial suspensions was determined by micro-Kjeldahl digestion and by the colorimetric Nessler procedure (Wilson \& Knight, I952). Numbers of Mycobacterium lepraemurium were determined by direct microscopic counts (Shepard \& McRae, I968).

Radiochemicals. Sodium $\left[\mathrm{I}-{ }^{14} \mathrm{C}\right]$ acetate, sodium $\left[2-{ }^{14} \mathrm{C}\right]$ acetate, L-[U-14 C]asparagine, D$\left[\mathrm{U}-{ }^{14} \mathrm{C}\right]$ glucose, L-[U-14 $\left.\mathrm{C}\right]$ glutamine, $\left[{ }^{2-14} \mathrm{C}\right]$ glycerol, $\left[\mathrm{U}-{ }^{14} \mathrm{C}\right]$ glycerol, and $\left[\mathrm{I}, 4-{ }^{14} \mathrm{C}\right]$ succinic acid were purchased from New England Nuclear Corporation, Boston, Massachusetts, U.S.A. $\left[\mathrm{I}, 4^{-14} \mathrm{C}\right]$ Fumaric acid and sodium $\left[5^{-14} \mathrm{C}\right] 2$-ketoglutarate were from Amersham/ Searle Corporation, Des Plaines, Illinois, U.S.A.

\section{RESULTS}

Oxidation of glycerol and acetate. The oxidation of glycerol and acetate by Mycobacterium lepraemurium under conditions which promote elongation of the organism have been described previously (Tepper, 197I). In the experiments shown in Fig. 2 and 3, the mycobacterial concentration exposed to the labelled substrate was increased from $\mathrm{IO}^{7}$ to $\mathrm{IO}^{9}$ bacteria $/ \mathrm{ml}$. At this density $M$. lepraemurium did not elongate during the incubation periods used. The substrate oxidations observed were therefore independent of the process of elongation.

The relationship between glycerol and acetate metabolism are shown in Fig. 3. The lower sigmoid curve is typical of oxidative rates in the complete elongation medium. When glycerol was omitted from the medium, there was an increase in the amount of ${ }^{14} \mathrm{CO}_{2}$ from $\left[{ }^{14} \mathrm{C}\right]-$ acetate. The products of glycerol metabolism apparently competed with and reduced exogenous acetate metabolism in this organism. This observation suggested that the oxidation of other substrates might be suppressed by the nutrients in the complex Hart-Valentine medium.

Effect of the suspending medium on substrate utilization. The reaction mixtures compared were the complex Hart-Valentine elongation medium (Hart \& Valentine, 1963), a chemically defined modified Kirchner medium (Tepper, I968); Sorenson's buffer (0.067 $\mathrm{M}-\mathrm{Na}_{2} \mathrm{HPO}_{4}$ ) $\mathrm{KH}_{2} \mathrm{PO}_{4}$ ) with and without asparagine $(0.6 \%$, w/v); and the $\mathrm{K}-36$ diluent of Weiss (1965) $\left(0 . \mathrm{I} \mathrm{M}-\mathrm{KCl}, 0.015 \mathrm{M}-\mathrm{NaCl}, 0.05 \mathrm{M}-\mathrm{KH}_{2} \mathrm{PO}_{4}\right)$ with and without asparagine $(0.6 \%$, w/v). An apparent four- to fivefold increase in oxidative activity occurred in the simpler media (Fig. 4a). The reduction in ${ }^{14} \mathrm{CO}_{2}$ from $\left[{ }^{14} \mathrm{C}\right]$ acetate in the presence of unlabelled glycerol also occurred in the nutritionally simpler Kirchner medium, while glucose did not interfere with acetate metabolism. Increased substrate incorporation into mycobacterial material was also associated with the decreased complexity of the exposure medium (Fig. $4 b$ ). Substrate assimilation in the buffer reaction mixture was 2 to 2.5 times greater than in the Hart- 


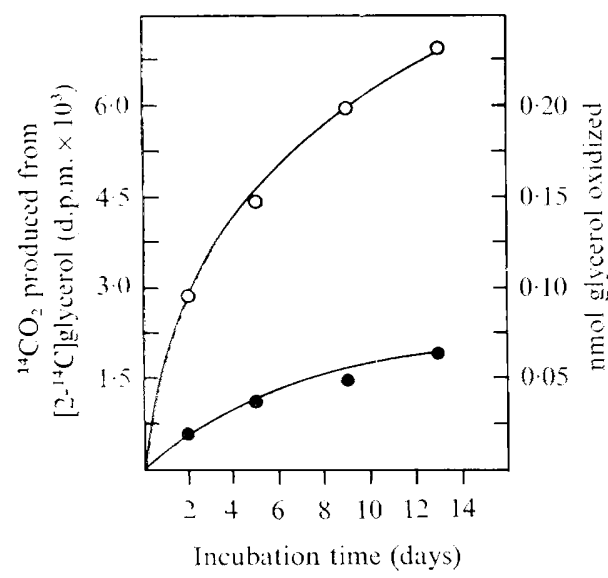

Fig. 2

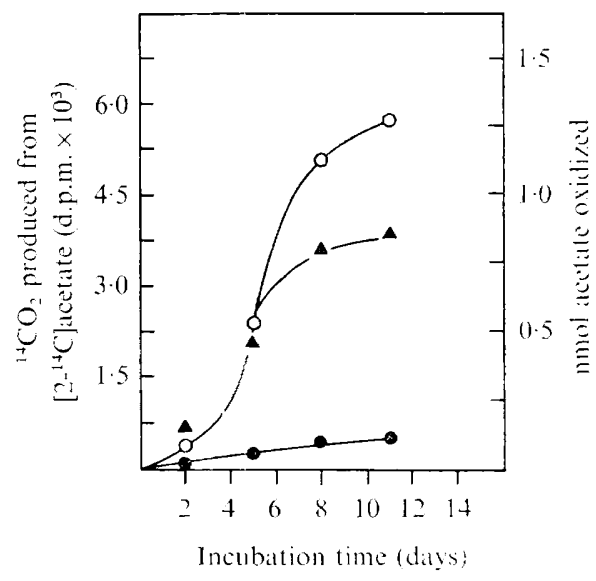

Fig. 3

Fig. 2. The carbon dioxide production from glycerol by Mycobacterium lepraemurium. Each reaction flask (O) contained Hart-Valentine medium without glycerol $(\mathrm{pH} 6 \cdot 2), 5 \mu \mathrm{Ci}\left[2-{ }^{14} \mathrm{C}\right]$ glycerol ( $13.6 \mu \mathrm{Ci} / \mu \mathrm{mol})$, and purified $M$. lepraemurium $(0.37 \mathrm{mg}$ bacterial nitrogen/flask); total volume $10 \mathrm{ml}$. Control flasks $(-)$ contained medium and $\left[2-{ }^{14} \mathrm{C}\right]$ glycerol without bacteria. All flasks were incubated at $37^{\circ} \mathrm{C}$.

Fig. 3. The rate of carbon dioxide production from acetate by Mycobacterium lepraemurium in the presence and absence of glycerol. Flasks contained either the complete Hart-Valentine medium ( $\Delta$ ) or Hart-Valentine medium without glycerol $(\bigcirc), 5 \mu \mathrm{Ci}\left[2-{ }^{14} \mathrm{C}\right]$ acetate $(2 \mu \mathrm{Ci} / \mu \mathrm{mol})$, and purified $M$. lepraemurium ( $0.37 \mathrm{mg}$ bacterial nitrogen/flask); total volume $\mathrm{ro} \mathrm{ml}$. Controls $(O)$ contained complete medium and $\left[2-{ }^{14} \mathrm{C}\right]$ acetate without bacteria. All flasks were incubated at $37^{\circ} \mathrm{C}$.

Valentine medium. In terms of both oxidation and assimilation, the Sorenson buffer and Weiss K-36 diluent were equivalent and there appeared to be little advantage in the presence of exogenous asparagine. The $\mathrm{K}-36$ diluent was chosen for subsequent experiments because it provided the high $\mathrm{K}^{+}-\mathrm{Na}^{+}$ratio favoured by other intracellular parasites (Weiss, I965).

Effect of $\mathrm{pH}$. Comparative data for acetate oxidation and assimilation in the elongation medium and $\mathrm{K}-36$ diluent are given for four $\mathrm{pH}$ values (Fig. 5). Maximal activity was observed in both systems at $\mathrm{pH} 7$ and the activity at $\mathrm{pH} 8$ was higher than at $\mathrm{pH} 5$ and 6 . The $\mathrm{pH}$ for maximal elongation of Mycobacterium lepraemurium in the Hart-Valentine medium is $\mathrm{pH} 6 \cdot 2$. The difference in optima for elongation potential and metabolic activity cannot be explained at present.

Substrate utilization in the buffer system. Comparable tests were made with K-36 diluent, including additional substrates, among them carboxylic acid intermediates of the tricarboxylic acid cycle (Table I). With the exception of asparagine and glucose, all were oxidized and all were assimilated.

Variations in metabolic activity. In any given experiment, the variations in the rates of substrate utilization in replicate flasks were less than $10 \%$. However, the rates were not reproducible between experiments with different batches of bacteria. These variations are shown for acetate and $\alpha$-ketoglutarate in Table I. For six substrates (Fig. 6), increased substrate concentrations increased the rates of oxidation and incorporation. The rates remained relatively low and saturation kinetics were not observed. Glucose and asparagine were included in this experiment but were not oxidized at any concentration tested. The relationship between substrate concentration and activity may explain, in part, the variations observed between experiments. The trauma of the isolation procedures, differences in the 

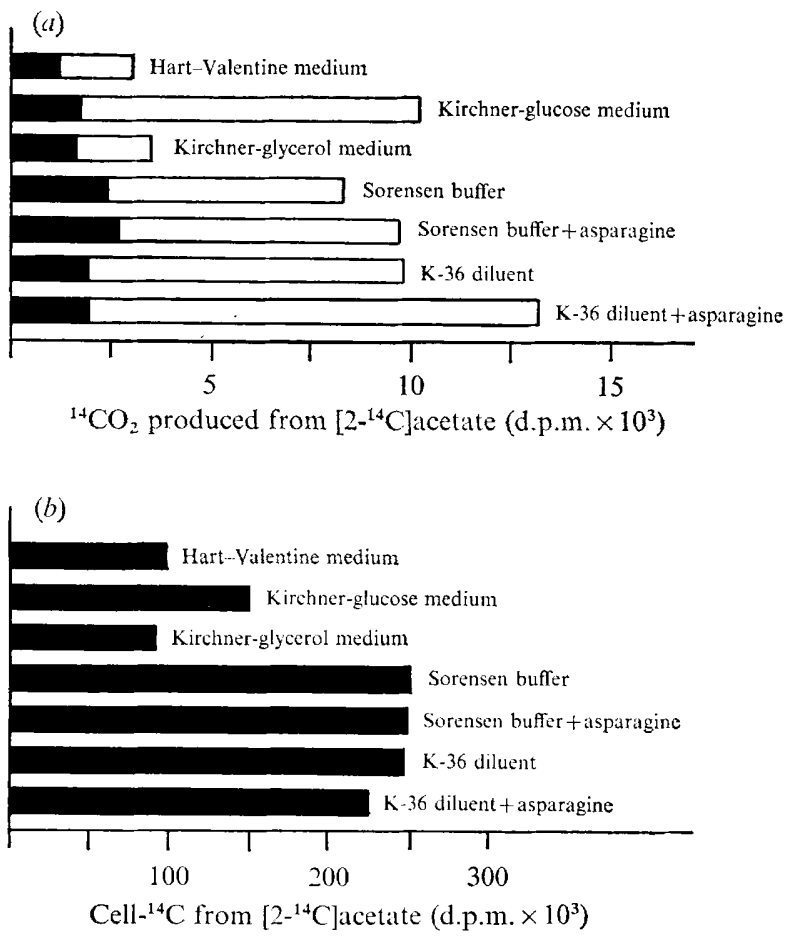

Fig. $4(a)$ The influence of the reaction medium on the oxidation of acetate by Mycobacterium lepraemurium. Flasks contained reaction medium, $5 \mu \mathrm{Ci}\left[2{ }^{14} \mathrm{C}\right]$ acetate $(2 \mu \mathrm{Ci} / \mu \mathrm{mol})$ and purified $M$. lepraemurium $(0.5 \mathrm{mg}$ bacterial nitrogen/flask); total volume $10 \mathrm{ml}$. The Hart-Valentine medium was at $\mathrm{pH} 6 \cdot 2$; all other reaction media were at $\mathrm{pH} 7 \cdot 0$; for details see text. Flasks were incubated at $37^{\circ} \mathrm{C}$ for I4 days. Dark shaded areas represent controls which did not contain bacteria. $(b)$ The influence of the reaction medium on the incorporation of acetate by $M$. lepraemurium. The Figure presents the ${ }^{14} \mathrm{C}$ incorporated by the $M$. lepraemurium used in the oxidation experiments in $4(a)$.
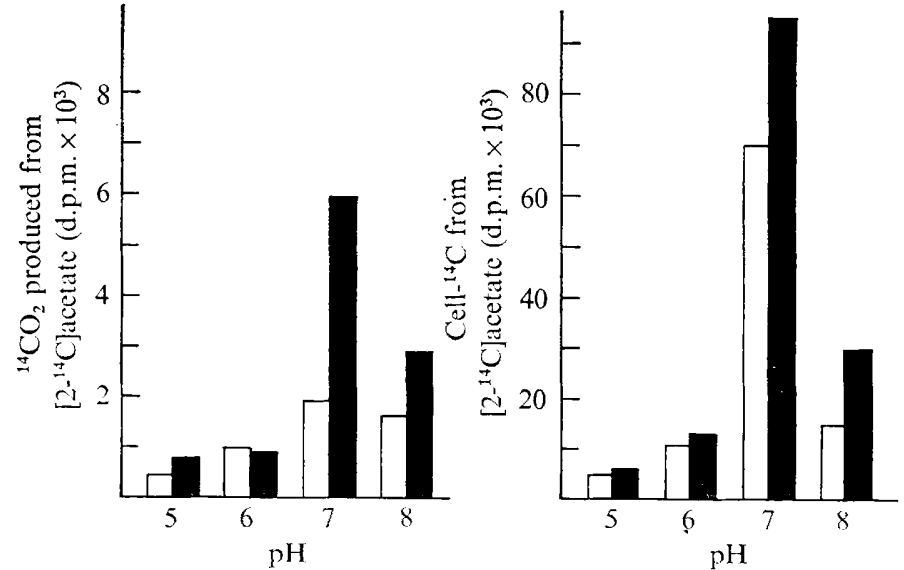

Fig. 5. The influence of $\mathrm{pH}$ on the oxidation and incorporation of acetate by Mycobacterium lepraemurium. Each flask contained either complete Hart-Valentine medium (opens bars) or K-36 diluent (shaded bars) at the indicated $\mathrm{pH}, 5 \mu \mathrm{Ci}\left[2{ }^{14} \mathrm{C}\right]$ acetate $(2 \mu \mathrm{Ci} / \mu \mathrm{mol})$ and purified $M$. lepraemurium $\left(0.23 \mathrm{mg}\right.$ bacterial nitrogen/flask); total volume $10 \mathrm{ml}$. Flasks were incubated at $37^{\circ} \mathrm{C}$ for 7 days. 
Table I. Oxidation and incorporation of ${ }^{14} \mathrm{C}$-labelled substrates by Mycobacterium lepraemurium

\begin{tabular}{|c|c|c|c|c|}
\hline \multirow[b]{2}{*}{${ }^{14} \mathrm{C}$-Substrate } & $\overbrace{{ }_{\text {formed }}^{14} \mathrm{CO}_{2}}^{\mathrm{D}}$ & 1. & \multicolumn{2}{|c|}{$\begin{array}{c}\mathrm{nmol} / \mathrm{mg} \\
\text { bacterial nitrogen }\end{array}$} \\
\hline & $\begin{array}{l}\text { from } \\
\text { labelled } \\
\text { carbon }\end{array}$ & $\begin{array}{c}{ }^{14} \mathrm{C} \\
\text { incor- } \\
\text { porated }\end{array}$ & $\begin{array}{l}\text { Oxidized } \\
\text { substrate }\end{array}$ & $\begin{array}{l}\text { Assimi- } \\
\text { lated } \\
\text { substrate }\end{array}$ \\
\hline \multicolumn{5}{|l|}{ Expt I* } \\
\hline $\begin{array}{l}{\left[I^{1+} \mathrm{C}\right] \text { Acetate }} \\
\text { control }\end{array}$ & $\begin{array}{r}357000 \\
\text { I } 010\end{array}$ & 26700 & $95 \cdot 4$ & $7 \cdot 2$ \\
\hline $\begin{array}{l}{\left[2-{ }^{14} \mathrm{C}\right] \text { Acetate }} \\
\text { control }\end{array}$ & $\begin{array}{r}403000 \\
2480\end{array}$ & 60400 & 107.4 & $16 \cdot 2$ \\
\hline $\begin{array}{l}{\left[\mathrm{U}-{ }^{14} \mathrm{C}\right] \text { Asparagine }} \\
\text { control }\end{array}$ & $\begin{array}{l}4490 \\
7270\end{array}$ & 366000 & - & $I \cdot I$ \\
\hline $\begin{array}{l}{\left[\mathrm{I}, 4^{-11} \mathrm{C}\right] \mathrm{F} \text { umarate }} \\
\text { control }\end{array}$ & $\begin{array}{r}119000 \\
26700\end{array}$ & 5520 & $4 \cdot I$ & 0.3 \\
\hline $\begin{array}{l}{\left[\mathrm{U}-{ }^{14} \mathrm{C}\right] \text { Glucose }} \\
\text { control }\end{array}$ & $\begin{array}{l}\text { II } 200 \\
\text { I } 5300\end{array}$ & 3210 & - & 0.3 \\
\hline $\begin{array}{l}{\left[\mathrm{U}-{ }^{14} \mathrm{C}\right] \text { Glycerol }} \\
\text { control }\end{array}$ & $\begin{array}{r}203000 \\
17400\end{array}$ & 82200 & I $2 \cdot I$ & $5 \cdot 3$ \\
\hline $\begin{array}{l}{\left[5^{14} \mathrm{C}\right] \alpha-\text { Ketoglutarate }} \\
\quad \text { control }\end{array}$ & $\begin{array}{l}38200 \\
21800\end{array}$ & 2010 & 0.5 & $0 . I$ \\
\hline \multicolumn{5}{|l|}{ Expt $2 \dagger$} \\
\hline $\begin{array}{l}{\left[\mathrm{I}^{-14} \mathrm{C}\right] \text { Acetate }} \\
\text { control }\end{array}$ & $\begin{array}{r}21800 \\
722\end{array}$ & I 3400 & $198 \cdot 0$ & I $22 \cdot 0$ \\
\hline $\begin{array}{l}{\left[1,4^{-14} \mathrm{C}\right] \text { Fumarate }} \\
\text { control }\end{array}$ & $\begin{array}{rl}27 & 900 \\
5 & 360\end{array}$ & 695 & $7 \cdot 1$ & 0.2 \\
\hline $\begin{array}{l}{\left[5^{-14} \mathrm{C}\right] \alpha-\text { Ketoglutarate }} \\
\quad \text { control }\end{array}$ & $\begin{array}{r}1910000 \\
4080\end{array}$ & 60000 & $125^{\circ} 0$ & $4 \cdot 0$ \\
\hline $\begin{array}{l}{\left[\mathrm{I}, 4^{-14} \mathrm{C}\right] \text { Succinate }} \\
\text { control }\end{array}$ & $\begin{array}{r}24600 \\
58\end{array}$ & 3340 & $4 \cdot 5$ & 0.6 \\
\hline
\end{tabular}

* Each flask contained Mycobacterium lepraemurium ( $0.84 \mathrm{mg}$ bacterial nitrogen), the ${ }^{14} \mathrm{C}$-substrate, and $\mathrm{K}-36$ diluent at $\mathrm{pH} 7 \cdot 0$; total volume $10 \mathrm{ml}$. Flasks were incubated at $37^{\circ} \mathrm{C}$ for 7 days. Substrate concentrations and specific activities were $0.25 \mathrm{~mm}-\left[\mathrm{I}-{ }^{14} \mathrm{C}\right]$ acetate $(2 \cdot 0 \mu \mathrm{Ci} / \mu \mathrm{mol}) ; 0.25 \mathrm{~mm}-\left[2-{ }^{14} \mathrm{C}\right]$ acetate $(2 \cdot 0 \mu \mathrm{Ci} /$ $\mu \mathrm{mol}) ; 0.03 \mathrm{mM}-\left[\mathrm{U}-{ }^{14} \mathrm{C}\right]$ asparagine $(179 \mu \mathrm{Ci} / \mu \mathrm{mol}) ; 0.04 \mathrm{mM}-\left[\mathrm{I}, 44^{-14} \mathrm{C}\right]$ fumarate (I $\left.2 \mu \mathrm{Ci} / \mu \mathrm{mol}\right) ; 0.09 \mathrm{~mm}-$ [U- $\left.{ }^{14} \mathrm{C}\right]$ glucose $(5 \cdot 2 \mu \mathrm{Ci} / \mu \mathrm{mol}) ; 0.06 \mathrm{~mm}-\left[\mathrm{U}-{ }^{14} \mathrm{C}\right] \mathrm{glycerol}(8.34 \mu \mathrm{Ci} / \mathrm{mol})$; and $0.03 \mathrm{~mm}-\left[5^{-14} \mathrm{C}\right] \alpha$-ketoglutarate ( $17 \cdot \mathrm{I} \mu \mathrm{Ci} / \mu \mathrm{mol})$.

$\uparrow$ Each flask contained Mycobacterium lepraemurium ( $0.4 \mathrm{mg}$ bacterial nitrogen), the ${ }^{14} \mathrm{C}$-substrate, and $\mathrm{K}-36$ diluent at $\mathrm{pH} 7 \cdot 0$; total volume $10 \mathrm{ml}$. Flasks were incubated at $37^{\circ} \mathrm{C}$ for 7 days. Substrate concentrations and specific activities were $4 \mathrm{~mm}-\left[\mathrm{I}-{ }^{14} \mathrm{C}\right]$ acetate $(0 \cdot \mathrm{I} 2 \mu \mathrm{Ci} / \mu \mathrm{mol}) ; 0 \cdot 14 \mathrm{~mm}-\left[\mathrm{I}, 4^{-14} \mathrm{C}\right]$ fumarate $(3.6 \mu \mathrm{Ci} /$ $\mu \mathrm{mol}) ; 0.14 \mathrm{~mm}-\left[5^{-14} \mathrm{C}\right] \alpha$-ketoglutarate (17. I $\left.\mu \mathrm{Ci} / \mu \mathrm{mol}\right)$; and $0.80 \mathrm{~mm}-\left[\mathrm{I}, 4^{\left.-{ }^{14} \mathrm{C}\right] \mathrm{succinate}}(6 \cdot 28 \mu \mathrm{Ci} / \mu \mathrm{mol})\right.$.

physiological age of the bacilli, and the proportion of degenerate bacilli in the Mycobacterium lepraemurium suspensions are also important considerations; however, the hostdependency of the organism and inadequate methods for estimating viability make these variables difficult to assess.

\section{DISCUSSION}

The results presented here demonstrate that Mycobacterium lepraemurium, when separated from its host cell, oxidized and assimilated exogenous substrates. The radiometric technique provided a more discriminitive method than the dye reduction or manometric procedures. 

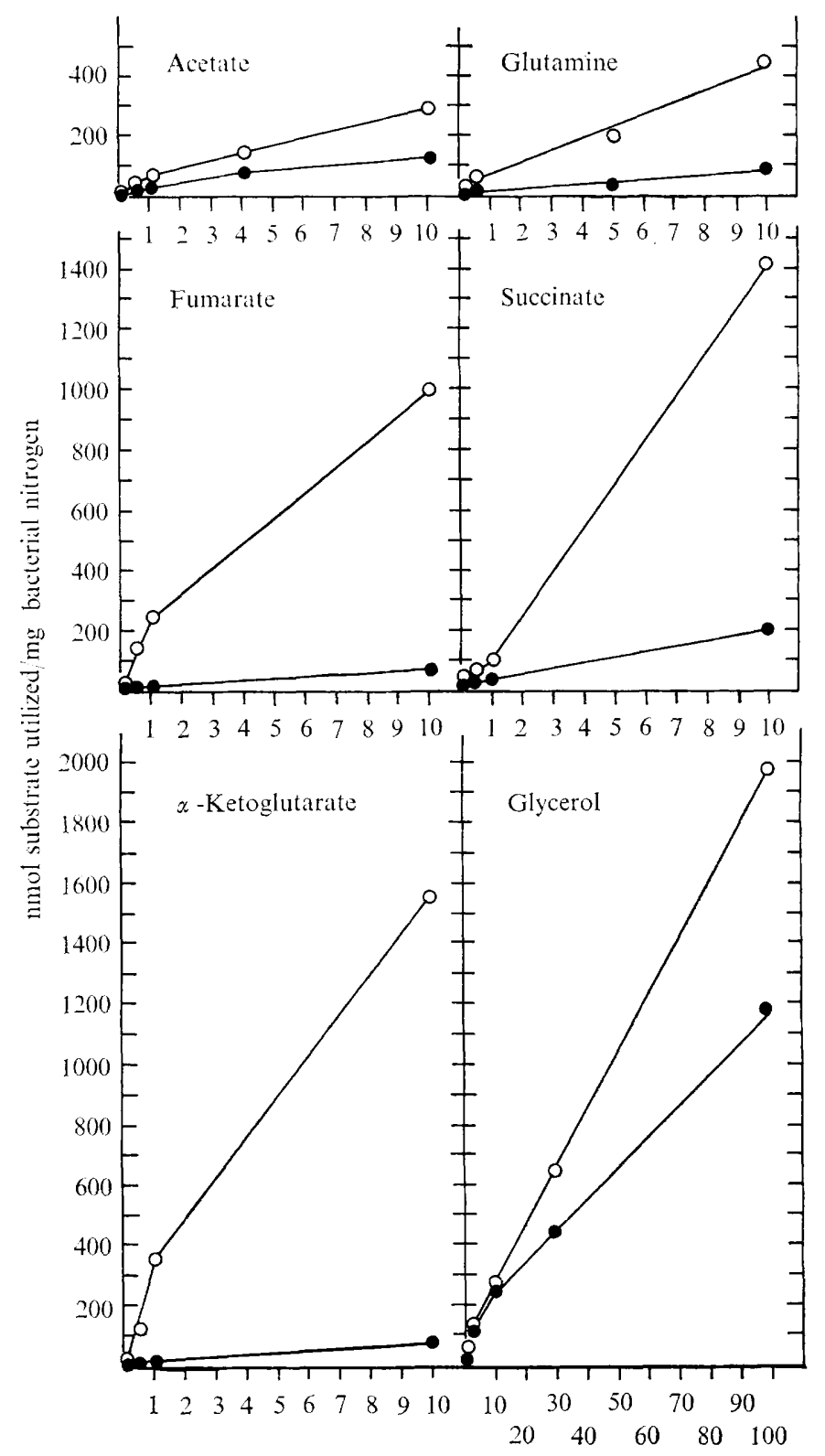

Substrate concentration (mM)

Fig. 6. The kinetics of substrate utilization by Mycobacterium lepraemurium. Each flask contained K-36 diluent, substrate at the indicated concentration containing $5 \mu \mathrm{Ci}$ of the ${ }^{14} \mathrm{C}$-labelled substrate, and purified $M$. lepraemurium $(0.25 \mathrm{mg}$ bacterial nitrogen/flask); total volume $10 \mathrm{ml}$. The labelled substrates were $\left[2^{-14} \mathrm{C}\right] a c e t a t e$, [U-14 Clglutamine, $\left[\mathrm{I}, 4^{-14} \mathrm{C}\right]$ fumarate, $\left[1,4^{-14} \mathrm{C}\right]$ succinate, $\left[5^{-14} \mathrm{C}\right] \alpha-$ ketoglutarate, and $\left[\mathrm{U}^{-14} \mathrm{C}\right]$ glycerol. All flasks were incubated at $37^{\circ} \mathrm{C}$ for 7 days. Values for controls for each substrate were subtracted from the data presented for oxidative activity. $O-C$, Substrate oxidized; - - substrate incorporated. Note that glycerol was tested at concentrations ro times greater than the other substrates. 
Previous workers may have failed to demonstrate substrate oxidations because the latter methods can detect exogenous substrate oxidations only as increases in the respiratory rate above that of endogenous respiration. The use of isotopic tracers permitted monitoring of substrate utilization without requisite changes in respiratory rates.

Many of the enzymes involved in the oxidation of the substrates listed in Table I have been demonstrated in disrupted Mycobacterium lepraemurium. They include citrate synthase, aconitate hydratase, isocitrate lyase, succinate dehydrogenase and fumarate hydratase (Mori, Kohsaka \& Tanaka, 1972). Pyruvate and $\alpha$-ketoglutarate dehydrogenase activities could not be demonstrated. The presence of isocitrate lyase and the lack of $\alpha$-ketoglutarate dehydrogenase activity prompted the conclusion that a glyoxalate cycle was active in $M$. lepraemurium. In our experiments with intact $M$. lepraemurium, the ${ }^{14} \mathrm{CO}_{2}$ produced from $\left[5^{-14} \mathrm{C}\right] \alpha$-ketoglutarate suggests that $\alpha$-ketoglutarate gives rise to succinate, where the $\left[5^{-14} \mathrm{C}\right]$ is randomized as $\left[\mathrm{I}, 4^{-14} \mathrm{C}\right]$ succinate, which is subsequently metabolized. Taken together with the observed oxidations of $\left[\mathrm{I}^{-14} \mathrm{C}\right]$ and $\left[2{ }^{14} \mathrm{C}\right]$ acetate, $\left[\mathrm{I}, 4^{-14} \mathrm{C}\right]$ succinate and $\left[1,4^{-14} \mathrm{C}\right]$ fumarate, these observations are consistent with the existence of a tricarboxylic acid cycle. However, the demonstration of isotope equilibrium among isolated intermediates of the cycle is still required for formal proof of a functional tricarboxylic acid cycle as the oxidative mechanism in $M$. lepraemurium.

The observed oxidation of glycerol and the experiments in which ${ }^{14} \mathrm{CO}_{2}$ from $\left[{ }^{14} \mathrm{C}\right]$ acetate was reduced when glycerol was present in two different media suggested that the catabolism of these substrates involves a common pathway. Considering the known mechanisms for glycerol catabolism, the evidence indicates that glycerol is metabolized via the triose portion of the glycolytic pathway through pyruvate, acetyl-CoA and the tricarboxylic acid cycle. The failure of Mycobacterium lepraemurium to catabolize glucose was particularly informative, especially since glucose was incorporated by these mycobacteria (Table I). The data which showed that exogenous glucose did not diminish the ${ }^{14} \mathrm{CO}_{2}$ produced from the oxidation of $\left[{ }^{14} \mathrm{C}\right]$ acetate provided further evidence for the failure of these bacteria to catabolize glucose. These observations suggest that glucose may not adequately permeate $M$. lepraemurium or that, in these mycobacteria, the triose portion of the glycolytic pathway may function for both energetic and biosynthetic purposes and that the 'hexose' portion of the pathway is largely synthetic. These hypotheses are being tested experimentally.

When compared with other host-dependent bacteria, Mycobacterium lepraemurium appears to be more competent metabolically than either the rickettsiae or the chlamydiae (Weiss, 1968). Mycobacterium lepraemurium is similar to the rickettsiae in that it catabolized many low molecular weight molecules, did not require added co-factors for these reactions, and failed to catabolize glucose. This bacillus differed from both organisms by not requiring added co-factors for the synthesis of macromolecules. The pattern of assimilation observed in our studies, and the composition changes observed during elongation in vitro, indicate that the exogenous substrates provided both the carbon skeleton and the energy for synthesis in $M$. lepraemurium.

The catabolic and assimilatory rates observed with Mycobacterium lepraemurium were extremely low (Table I) and did not improve greatly at increased substrate concentrations (Fig. 6). With different batches of bacteria, variations occurred in metabolic rates and in the ratios of substrate oxidized to substrate assimilated. It seems unlikely that these variations can be ascribed to the experimental technique but, rather, they appear related to the physiological state of the mycobacteria harvested. The numbers of bacteria required for these experiments suggests that a large proportion are in various stages of degeneration and this proportion may vary in different harvests. Studies, now in progress, are designed to determine 
whether correlations exist between metabolic activity and the duration of the infection in $M$. lepraemurium isolated from different organs.

This investigation was supported by Public Health Service grants AI-06944 and AI-09763 from the National Institute of Allergy and Infectious Diseases.

\section{REFERENCES}

BrAY, G. A. (I960). A simple efficient liquid scintillator for counting aqueous solutions in a liquid scintillation counter. Analytical Biochemistry $1,279-285$.

DraPER, P. \& HART, P. D'ARCY (1968). The composition of normal and elongated Mycobacterium lepraemurium. Journal of General Microbiology 52, $18 \mathrm{I}-188$.

Fain, J. N., Scow, R. O. \& Chernick, S. S. (1963). Effects of glucocorticoides on metabolism of adipose tissue in vitro. Journal of Biological Chemistry 238, 54-58.

GRAY, C. T. (1952). The respiratory metabolism of murine leprosy bacilli. Journal of Bacteriology 64, 305-31 3 .

HANKs, J. H. (195I a). Measurement of the hydrogen transfer capacity of mycobacteria. Journal of Bacteri$\operatorname{olog} y$ 62, $52 \mathrm{I}-528$.

HANKS, J. H. (195I $b$ ). The biological significance of the hydrogen transfer capacity of murine leprosy bacilli. Journal of Bacteriology 62, 529-537.

HANKs, J. H. (1954). Influence of physical and chemical factors on the hydrogen transfer capacity of murine leprosy. International Journal of Leprosy 22, 162-172.

Hart, P. D'Arcy \& Valentine, R. C. (1963). Growth (without multiplication) of Mycobacterium lepraemurium in cell-free medium. Journal of General Microbiology 32, 43-53.

ITO, T. \& SonADA, R. (1958). Biochemical studies on the murine leprosy bacillus. II. Respiration and respiration-accelerating substances. Biken's Journal I, 157-165.

KusAKA, T. (1958a). Studies on the metabolism of murine leprosy bacilli. I. Stimulating effect of mitochondria extract of rat liver on the metabolism of bacilli. Japanese Journal of Medical Science and Biology II, 277-285.

KusAKA, T. (1958b). Studies on the metabolism of murine leprosy bacilli. II. Substances, contained in mitochondria extract of rat liver, which stimulate the metabolism of bacilli and some enzyme systems in the bacilli. Japanese Journal of Medical Science and Biology II, 287-293.

KUSAKA, T. (1959). D-Ribose as a simple respiration stimulating substance on murine leprosy bacilli without requiring any cofactor. Journal of Biochemistry, Tokyo 46, 395-396.

Mori, T., Kohsaka, K. \& TanaKa, Y. (I972). Enzyme systems of the tricarboxylic acid cycle in Mycobacterium lepraemurium. International Journal of Leprosy 39, (in the press).

Nishimura, S., Ito, T., Mori, T., Kohsaka, K. \& Kawagurchi, Y. (1967). Murine leprosy. VII. Guide to experimental methods for murine leprosy. In Mykobakterien und mykobakterielle Krankheiten, vol. $\mathrm{xx}$, pp. 382-394. Edited by G. Meissner and A. Schmeidel. Jena: VEB Gustav Fishcher Verlag.

ShePARD, C. C. \& MCRAE, D. H. (1968). A method for counting acid-fast bacteria. International Journal of Leprosy 36, 78-82.

TAmemasa, O. \& Tsutsumi, S. (1958). On the metabolism of mycobacteria. I. Dehydrogenase activities of Mycobacterium lepraemurium. Japanese Journal of Experimental Medicine 28, 183-197.

TEPPER, B. S. (1968). Differences in the utilization of glycerol and glucose by Mycobacterium phlei. Journal of Bacteriology 95, I71 3-1717.

TEPPER, B. S. (197I). Problems in the cultivation of Mycobacterium leprae. Related cultivation and biochemical studies with Mycobacterium lepraemurium. International Journal of Leprosy 39, 323-327.

VALENTINE, R. C. (1962). Quantitative electron microscopy of leprosy bacilli. British Medical Bulletin I8, $242-244$.

WeIss, E. (1965). Adenosine triphosphate and other requirements for the utilization of glucose by agents of the psittacosis-trachoma group. Journal of Bacteriology 90, 243-253.

Werss, E. (I968). Comparative metabolism of rickettsiae and other host dependent bacteria. Zentralblatt für Bakteriologie, Parasitenkunde, Infektionskrankheiten und Hygiene (Abteilung I. Originala) 206, 292-298.

WiLsON, P. W. \& KNıGHT, S. G. (1952). Experiments in Bacterial Physiology. Minneapolis: Burgess Publishing Co. 